\title{
Nursing support perceived by mothers of preterm infants in a neonatal intensive care unit in South Korea
}

\author{
Mihae $\mathrm{Im}^{1}$, Jina $\mathrm{Oh}^{2}$ \\ ${ }^{1}$ Assistant Professor, Department of Nursing, Choonhae College of Health Science, Ulsan; ${ }^{2}$ Professor, Institute of Health Science, College of Nursing, Inje \\ University, Busan, Korea
}

Purpose: The aim of this study was to clarify and define the concept of nursing support as perceived by mothers of preterm infants. Methods: The research was conducted using Schwartz-Barcott and Kim's hybrid model. Sixteen articles were analyzed during the theoretical phase. In-depth interviews were conducted with 10 mothers of preterm infants in the fieldwork phase. In the final analytical phase, the attributes of nursing support were defined. Results: There were four themes and 10 attributes of nursing support as perceived by mothers of preterm infants. Professional care and emotional care for the baby were identified as attributes of baby care support. Information related to the disease, inpatient environment, baby's daily hospital life, and mother-centered care were identified as attributes of information delivery support. Empathy for mothers and therapeutic communication with the mother were identified as attributes for mental care support. Lastly, providing a chance for the mother to take care of the baby and reinforcement of the maternal role were identified as attributes of maternal role support. Conclusion: The 10 attributes of this study could provide a base for the development of a nursing support instrument and practical guidelines for mothers in neonatal intensive care units.

Key words: Infant; Premature birth; Mothers; Intensive care units, neonatal

\author{
Corresponding author \\ Jina Oh \\ College of Nursing, Inje University, \\ 75 Bokji-ro, Busanjin-gu, Busan 47720, \\ Korea \\ TEL: +82-51-890-6833 \\ FAX: +82-51-896-9840 \\ E-MAIL: ohjina@inje.ac.kr
}

This article was adapted from a thesis by Mihae Im in partial fulfillment of the requirements for the dissertation at Inje University of Korea.
Received Jan 8, 2021
Revised Feb 8, 2021
Accepted Feb 17, 2021

This is an Open Access article distributed under the terms of the Creative Commons Attribution NonCommercial License (http//creativecommonsorg/licenses/by-nc/4.0n which pert//Creativecomons and reproduction in any medium, provided the original work is properly cited.

\section{INTRODUCTION}

Advances in medical technology and investments by hospitals and governments have improved the survival rate of premature infants from $40.6 \%$ to $64.2 \%$ [1]. Despite continuing developments and efforts to improve the survival rate of premature infants, there is a relative lack of interest in mothers who have given birth to premature infants [2]. Since family-centered care (FCC) is the core philosophy of pediatric nursing, it is important that mothers of infants born prematurely are also considered [3].

The mother of a premature infant experiences a high degree of role confusion and conflict due to the unexpected hospitalization of her baby and an unfamiliar medical environment [A15]. These mothers can suffer from frustration and guilt, presuming that baby's hospitalization is their own fault, and may experience attachment disorder as they are not able to fulfil their motherly duties as a result of being separated from the baby $[2,4, \mathrm{~A} 3]$. In addition, there may be a lack of specialized knowledge about the condition or disease of the baby, and the provision of information is limited to visiting hours, causing uncertainty, anxiety, and stress about the baby's disease and prognosis [5]. As a result, mothers of preterm infants experience difficulties in making decisions and are forced to entirely rely on health providers [6].

Nursing support is essential for mothers of premature infants [A1]. Through nursing support, mothers get information about the baby's treatment process, receive comfort, and regain their self-esteem as mothers [7,A3]. However, previous studies have focused on nurse-centered support, rather than client-centered support [5,A1,A10]. Moreover, the research on nursing support perceived by mothers is insufficient, as there is a discrepancy between nursing support as perceived by the mother and as perceived by nurses [A1,A10]. Nurses tended 
to think that they provided full emotional support to the parents with premature infants, while parents did not perceive enough support [3,A1]. Because the concept of support varies depending on subject and the environment $[8,9]$, it is necessary to identify the features of nursing support as perceived by the mothers of premature infants in the context of the neonatal intensive care unit (NICU).

In the current study, Schwartz-Barcott and Kim's [10] hybrid model was used to analyze the concept of nursing support. This model is a conceptual analysis method that combines theoretical and empirical analyses. It is a useful method for studying conceptual phenomena such as nursing support that are recognized in clinical practice [10]. The results of this study are expected to help define nursing support for mothers of premature infants, and provide theoretical evidence for the development of nursing support intervention programs.

\section{METHODS}

Ethics statement: This study was approved by the Institutional Review Board of Inje University (No. 2017-11-006-001). Informed consent was obtained from the participants.

\section{Study Design}

This study was conducted in three phases, theoretical, fieldwork, and analytical based on the hybrid model (Figure 1) [10]. In the theoretical phase, identified components were linked, compared, and contrasted with each other to determine the attributes and definitions of each concept, resulting in a working definition. The fieldwork phase was performed to confirm whether the attributes and definitions of concepts identified in the theoretical phase appeared in practice or if there were any additional unidentified attributes. The attributes identified in the theoretical phase and the attributes reconfirmed in the fieldwork phase were considered in the ana- lytical phase.

\section{Theoretical Phase}

After selecting the concept of nursing support perceived by mothers of premature infants, a literature review was conducted by checking the dictionary definition of nursing support, determining the meaning and components of support in nursing and other disciplines, and searching for articles related to nursing support for mothers of premature infants. A literature review was conducted focusing on the conceptual definitions and attributes of nursing support as perceived by mothers of premature infants. The period of publication of the literature was from 1979, when nursing support was defined by Gardner [9], to October 2019 Studies were retrieved from PubMed, Science Direct, Google Scholar, Scopus, and the Cumulative Index of Nursing and Allied Health Literature (CINHAL) as international databases, as well as from the DataBase Periodical Information Academic (DBpia), Korean Studies Information Service System (KISS), National Digital Science Library (NDSL), and Research Information Sharing Service (RISS) as South Korean databases. The databases were searched using a combination of search terms such as "preterm infant," "mother," "support," and "nursing." The inclusion criteria for this review were as follows: (a) peer-reviewed articles written in English and Korean, (b) nursing support for mothers or families with preterm infants in the NICU, (c) nursing support provided by NICU nurses, and (d) articles that included the definition or component of nursing support in the NICU. As a result, 16 articles were included in the theoretical stage (Figure 2).

Subsequently, an analysis framework was constructed to identify the contents and components of nursing support. For the quality appraisal of the studies, the Strengthening the Reporting of Observational Studies in Epidemiology (STROBE) checklist was used [11]. After sufficient discussion to allow researchers to understand the STROBE checklist at the same lev-

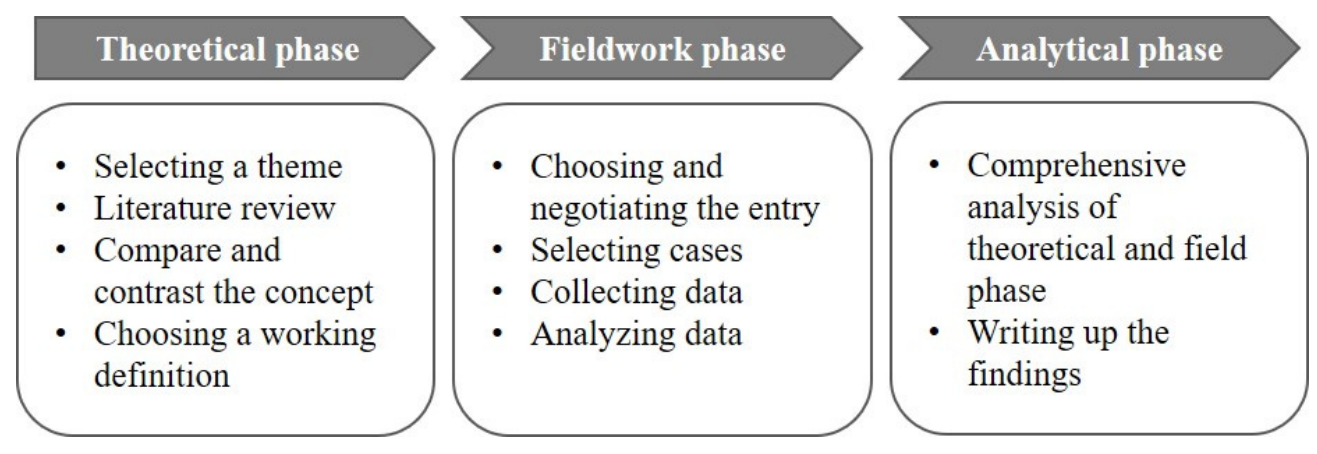

Figure 1. Process of research based on Schwartz-Barcott and Kim's hybrid model. 


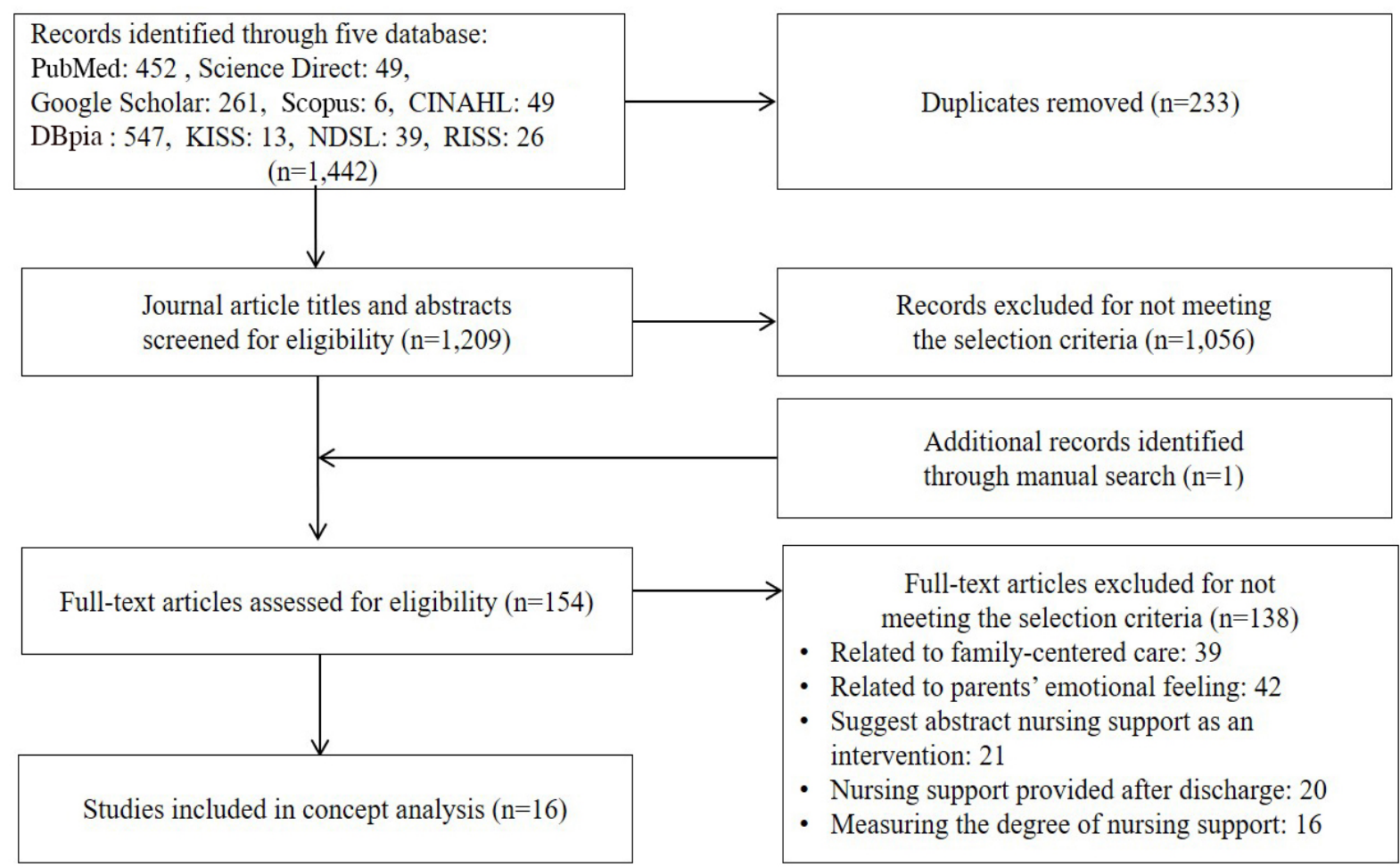

Figure 2. Flow chart of literature review. CINAHL, cumulative index of nursing and allied health literature; DBpia, database periodical information academic; KISS, Korean studies information service system; NDSL, national digital science library; RISS, research information sharing service.

el, each article was individually appraised by two authors. All selected articles passed the quality evaluation (Table 1).

\section{Fieldwork Phase}

In the fieldwork phase, the NICU was chosen as a fieldwork site since the concepts being studied could be observed frequently. Participants were selected for interviews based on an assessment of who could best explain the concept of nursing support perceived by mothers. Data were collected through in-depth interviews with participants.

\section{1) Selection of research participants}

The intention was to select people who could best explain the contexts of nursing support as perceived by mothers of premature infants in the NICU. Specific criteria for the selection of candidates were: a) mothers who understood the purpose of the study and agreed to participate, b) mothers of babies with a gestational age of less than 37 weeks, c) mothers of babies without congenital deformities and hereditary diseases, and d) mothers within a year of childbirth. The first suitable participant for this study was introduced by an NICU nurse where the researcher worked. Afterwards, the study subjects were introduced by other participants. The final number of participants was 10, at which point the data were deemed to be saturated (Table 2).

\section{2) Data collection}

The interviews were conducted from November 2017 to March 2018, and the schedule was prearranged through phone calls and text messages. The interviewer attempted to relieve the tension of the participants and to create a relaxed interview atmosphere. The interviews were conducted with semistructured, open questions based on the findings of the theoretical phase. The main question was, "What nursing support do you think a neonatal intensive care unit nurse provides?" Additional questions were asked such as "What are some examples of impressive nursing support that you received from the neonatal intensive care unit nurses?" and "What kind of nursing support was particularly needed for mothers of premature infants?" One or two in-depth interviews were conducted with each participant. The interviews lasted for 60 to 90 minutes.

\section{3) Data analysis}

A thematic analysis method was used to identify the key findings [12]. The in-depth interviews were recorded with the consent of the participants, and the researchers attempted to 
Table 1. Characteristics of Papers related to Nursing Support in Neonatal Intensive Care Unit $(N=16)$

\begin{tabular}{|c|c|c|c|c|c|}
\hline No. & $\begin{array}{l}\text { First author } \\
\text { (year) }\end{array}$ & Subjects & Components & Content of nursing support & Derived attributes \\
\hline A1 & $\begin{array}{l}\text { Mok } \\
(2006)\end{array}$ & $\begin{array}{l}6 \text { Mothers of } \\
\text { preterm infants }\end{array}$ & $\begin{array}{l}\text {-Communication } \\
\text { support } \\
\text {-Information } \\
\text { support } \\
\text {-Emotional support } \\
\text {-Esteem support } \\
\text {-Quality care } \\
\text { management }\end{array}$ & $\begin{array}{l}\text {-Communication and information support: Taking } \\
\text { the initiative to be open and honest, gave } \\
\text { comprehensive and clear information using simple } \\
\text { terms, nurses' availability } \\
\text { ·Emotional care: Trusting relationship, affection and } \\
\text { concern, listening, reassurance, answering } \\
\text { questions, mother feels comfortable to ask questions, } \\
\text { does not feel like a burden to the nurses } \\
\text {-Esteem support: Involvement care, assurance of } \\
\text { capability of being a mother, encouragement, } \\
\text { affirmation } \\
\text {-Quality care management: Giving good care, linking } \\
\text { mothers to other mothers of premature infants, } \\
\text { consistent policy }\end{array}$ & $\begin{array}{l}\text {-Attitudes of information providing } \\
\text { nurses } \\
\cdot \text { Therapeutic communication with the } \\
\text { mother } \\
\cdot \text { Improvement of the maternal role } \\
\cdot \text { Reinforcement of the maternal role }\end{array}$ \\
\hline A2 & $\begin{array}{l}\text { Kim } \\
(2009)\end{array}$ & $\begin{array}{l}21 \text { Mothers of } \\
\text { preterm infants }\end{array}$ & $\begin{array}{l}\text { - Informational } \\
\text { support } \\
\cdot \text { Psychosocial } \\
\text { support } \\
\text { - Direct care of baby } \\
\text { support }\end{array}$ & $\begin{array}{l}\text {-Nursing support program: Supportive } \\
\text { communication, encouragement, information } \\
\text { related to baby, and coping strategies after discharge } \\
\text { were provided }\end{array}$ & $\begin{array}{l}\text {-Providing information related to disease } \\
\text {-Providing information related to child } \\
\text { rearing } \\
\text {-Empathy for mothers } \\
\text { - Therapeutic communication with the } \\
\text { mother } \\
\text { - Caring for premature infants }\end{array}$ \\
\hline A3 & $\begin{array}{l}\text { Kearvell } \\
(2010)\end{array}$ & 24 Papers & $\begin{array}{l}\text { - Mother-infant } \\
\text { interaction } \\
\text { support } \\
\cdot \text { Mother-nurse } \\
\text { interaction } \\
\text { support }\end{array}$ & $\begin{array}{l}\text {-Tangible support: Kangaroo care, breastfeeding } \\
\text {-Participation in routine care: Nurturing actions and } \\
\text { contact such as talking, singing, comforting, etc. } \\
\text {-Psychosocial support: Providing support, assistance, } \\
\text { privacy, and positive and encouraging attitude } \\
\text { toward mothers throughout their experience } \\
\text {-Communication support: Providing constant } \\
\text { information and updates on the baby's health } \\
\text { condition }\end{array}$ & $\begin{array}{l}\text { - Providing information related to the } \\
\text { disease } \\
\text { - Empathy for mothers } \\
\text { - Therapeutic communication with the } \\
\text { mother } \\
\text {-Improvement of the maternal role }\end{array}$ \\
\hline A4 & $\begin{array}{l}\text { Brett } \\
(2011)\end{array}$ & 72 Papers & $\begin{array}{l}\text { Provision of } \\
\text { information } \\
\text { support } \\
\text {-Improved } \\
\text { communication } \\
\text { support }\end{array}$ & $\begin{array}{l}\text { Parents involvement: Involving parents in } \\
\text { individualized developmental and behavioral } \\
\text { programs, breastfeeding, kangaroo care, and } \\
\text { infant-massage programs } \\
\text { - Informational support: Forums for parents, } \\
\text { preparation of parents for various stages, } \\
\text { home-support programs }\end{array}$ & $\begin{array}{l}\text { - Providing information related to the } \\
\text { support system } \\
\text { - Improvement of the maternal role } \\
\text { - Therapeutic communication with the } \\
\text { mother }\end{array}$ \\
\hline A5 & $\begin{array}{r}\text { Bracht } \\
(2013)\end{array}$ & $\begin{array}{l}39 \text { Mothers of } \\
\text { preterm infants }\end{array}$ & $\begin{array}{l}\text {-Informational } \\
\text { support } \\
\text {-Emotional support }\end{array}$ & $\begin{array}{l}\text {-Information support: Sessions for education, } \\
\text { audiotaped and written material, education in } \\
\text { specific areas, such as breastfeeding, kangaroo care } \\
\text { and baby massage } \\
\text {-Emotional support: Ongoing weekly support } \\
\text { meetings, individualized psychosocial support }\end{array}$ & $\begin{array}{l}\text { Providing information related to the } \\
\text { disease } \\
\text {-Providing information related to child } \\
\text { rearing } \\
\text { - Empathy for mothers } \\
\text {-Therapeutic communication with the } \\
\text { mother }\end{array}$ \\
\hline A6 & $\begin{array}{l}\text { Doron } \\
(2013)\end{array}$ & None & $\begin{array}{l}\text {-Informational } \\
\text { support } \\
\text { - Involvement } \\
\text { support }\end{array}$ & $\begin{array}{l}\text {-Application: "Preemie" the ideal tool for providing } \\
\text { personalized information and support } \\
\text { - Pocket guide session: } 115 \text { Information related to } \\
\text { baby's condition } \\
\text {-Tracker section session: Empowers parents to } \\
\text { participate in decision making regarding their baby's } \\
\text { development and decreases their feelings of } \\
\text { exclusion } \\
\text {-Diary session: Empowers them by helping them } \\
\text { identify and remember special events, express their } \\
\text { emotions, and feel included in their baby's care }\end{array}$ & $\begin{array}{l}\text { Providing information related to the } \\
\text { disease } \\
\text { - Providing information related to child } \\
\text { rearing } \\
\text {-Improvement of the maternal role }\end{array}$ \\
\hline A7 & $\begin{array}{l}\text { Lee } \\
\qquad(2013)\end{array}$ & $\begin{array}{l}69 \text { Fathers of } \\
\text { hospitalized } \\
\text { infants in NICU }\end{array}$ & $\begin{array}{l}\cdot \text { Informational } \\
\text { support } \\
\cdot \text { Emotional support } \\
\cdot \text { Instrumental } \\
\text { support } \\
\cdot \text { Esteem support }\end{array}$ & $\begin{array}{l}\text { - Booklet: Contents consisted of "things a father must } \\
\text { know"; baby's developmental care, nutrition, } \\
\text { appearance, etc. } \\
\text {-Nursing guidance: Nurses listened to father's } \\
\text { concerns, guided the father to focus on the preterm } \\
\text { infant, and supported the father by applying } \\
\text { relaxation skills }\end{array}$ & $\begin{array}{l}\text { - Providing information related to the } \\
\text { disease } \\
\text {-Improvement of the maternal role } \\
\text { - Reinforcement of the maternal role } \\
\text { - Therapeutic communication with the } \\
\text { mother }\end{array}$ \\
\hline
\end{tabular}

NICU, neonatal intensive care unit. 
Table 1. Characteristics of Papers related to Nursing Support in Neonatal Intensive Care Unit (Continued) $(N=16)$

\begin{tabular}{|c|c|c|c|c|c|}
\hline No. & $\begin{array}{l}\text { First author } \\
\text { (year) }\end{array}$ & Subjects & Components & Content of nursing support & Derived attributes \\
\hline A8 & $\begin{array}{l}\text { Abdeyazdan } \\
(2014)\end{array}$ & $\begin{array}{l}50 \text { Parents of } \\
\text { preterm infants }\end{array}$ & $\begin{array}{l}\cdot \text { Educational } \\
\text { support } \\
\cdot \text { Emotional support }\end{array}$ & $\begin{array}{l}\text {-Informational support: Environment, equipment, } \\
\text { and medical staff of the NICU, care procedures, } \\
\text { characteristics of premature infants, common } \\
\text { medical terminology in the NICU, possible feelings } \\
\text { of parents during their infant's hospitalization, and } \\
\text { methods of participation in infant care. } 2 \text { books and } \\
\text { educational booklets were provided } \\
\text {-Provision support: Received psychological training } \\
\text { were given the opportunity to share their feelings } \\
\text { and experiences with other parents of premature } \\
\text { infants }\end{array}$ & $\begin{array}{l}\text { - Providing information related to the } \\
\text { support system } \\
\text { - Empathy for mothers } \\
\text { - Therapeutic communication with the } \\
\text { mother }\end{array}$ \\
\hline A9 & $\begin{array}{l}\text { Han } \\
(2016)\end{array}$ & $\begin{array}{l}88 \text { Fathers of } \\
\text { hospitalized } \\
\text { infants in NICU }\end{array}$ & $\begin{array}{l}\text { - Emotional support } \\
\text {-Informational } \\
\text { support } \\
\text {-Involvement } \\
\text { support }\end{array}$ & $\begin{array}{l}\text {-Informational support: Providing information } \\
\text { related to treatment being performed, medical } \\
\text { device attached to the baby, and explanation in } \\
\text { simple and understandable terms } \\
\text {-Emotional support: Showing interest in the state of } \\
\text { father's feeling } \\
\text { - Involvement support: Encourage father's } \\
\text { participation in baby's care }\end{array}$ & $\begin{array}{l}\text { Providing information related to the } \\
\text { disease } \\
\text { - Empathy for mothers } \\
\text {-Improvement of the maternal role }\end{array}$ \\
\hline A10 & $\begin{array}{l}\text { Toral-López } \\
\text { (2016) }\end{array}$ & $\begin{array}{l}23 \text { Parents of } \\
\text { preterm infants }\end{array}$ & -Emotional support & $\begin{array}{l}\text {-Emotional support: Health staff's empathy and } \\
\text { values as well as how they addressed their } \\
\text { emotional and care needs. }\end{array}$ & -Empathy for mothers \\
\hline A11 & $\begin{array}{l}\text { Heydarpour } \\
(2017)\end{array}$ & $\begin{array}{l}17 \text { Mothers of } \\
\text { preterm infants }\end{array}$ & $\begin{array}{l}\text {-Informational } \\
\text { support }\end{array}$ & $\begin{array}{l}\text { Giving information: Infant's condition, answering } \\
\text { their questions without being angry, and guide them }\end{array}$ & $\begin{array}{l}\text { Providing information related to } \\
\text { disease } \\
\text {-Attitudes of information providing } \\
\text { nurses }\end{array}$ \\
\hline A12 & $\begin{array}{l}\text { Huenink } \\
(2017)\end{array}$ & $\begin{array}{l}101 \text { Parents of } \\
\text { hospitalized } \\
\text { infants in NICU }\end{array}$ & $\begin{array}{l}\cdot \text { Informational } \\
\text { support } \\
\cdot \text { Emotional support }\end{array}$ & $\begin{array}{l}\text { Parent-to-parent programs: Provide written and } \\
\text { verbal information about the NICU, as well as give } \\
\text { parents an opportunity to meet each other } \\
\text {-Journaling programs: Writing down thoughts, ideas, } \\
\text { and feelings } \\
\text {-Scrapbooking programs: Family getting together } \\
\text { and create books with collected mementos and } \\
\text { photographs of their child }\end{array}$ & $\begin{array}{l}\text { Providing information related to the } \\
\text { support system } \\
\text {-Therapeutic communication with the } \\
\text { mother }\end{array}$ \\
\hline A13 & $\begin{array}{l}\text { Shimizu } \\
\text { (2018) }\end{array}$ & $\begin{array}{l}98 \text { Mothers of } \\
\text { hospitalized } \\
\text { infants in NICU }\end{array}$ & $\begin{array}{l}\cdot \text { Comfort support } \\
\cdot \text { Trust support } \\
\cdot \text { Autonomy } \\
\text { support } \\
\text { - Family- centered } \\
\text { support }\end{array}$ & $\begin{array}{l}\text {-Emotional support: Consideration of parents' } \\
\text { feelings } \\
\text {-Informational support: Provision of parent-friendly } \\
\text { visual information } \\
\text {-Empowerment support: Ability to deal with specific } \\
\text { needs, coordination in dealing with situations }\end{array}$ & $\begin{array}{l}\text {-Empathy for mothers } \\
\text {-Providing information related to } \\
\text { disease } \\
\text { - Reinforcement of the maternal role }\end{array}$ \\
\hline A14 & $\begin{array}{l}\text { Tandberg } \\
(2018)\end{array}$ & $\begin{array}{l}115 \text { Parents of } \\
\text { preterm infants }\end{array}$ & $\begin{array}{l}\cdot \text { Guidance support } \\
\cdot \text { Information } \\
\text { support } \\
\cdot \text { Emotional support }\end{array}$ & $\begin{array}{l}\text {-Involvement care: Parents participating in care, } \\
\text { participation in medical rounds } \\
\text {-Trust formation: Building trust between parents and } \\
\text { nurses } \\
\text {-Giving information: Guidance provided by nurses, } \\
\text { individualized information } \\
\text {-Emotional support: Parents being heard, spending } \\
\text { time together }\end{array}$ & $\begin{array}{l}\text {-Improvement of maternal care } \\
\text { - Therapeutic communication with the } \\
\text { mother } \\
\text {-Providing information related to } \\
\text { disease }\end{array}$ \\
\hline A15 & $\begin{array}{l}\text { Bry } \\
(2019)\end{array}$ & $\begin{array}{l}28 \text { Parents after } \\
\text { their infant's } \\
\text { discharge from } \\
\text { the NICU }\end{array}$ & $\begin{array}{l}\text { Psychosocial } \\
\text { support }\end{array}$ & $\begin{array}{l}\text { Emotional support: Feeling able to trust the health } \\
\text { care provider, support in balancing time with the } \\
\text { infant and other responsibilities, keep parents' } \\
\text { privacy }\end{array}$ & $\begin{array}{l}\text { - Empathy for mothers } \\
\text {-Therapeutic communication with the } \\
\text { mother }\end{array}$ \\
\hline A16 & $\begin{array}{l}\text { Flacking } \\
\text { (2019) }\end{array}$ & $\begin{array}{l}34 \text { NICUs in } \\
\text { Sweden }\end{array}$ & $\cdot$ Emotional support & $\begin{array}{l}\text { - Psychologist or social worker: Offer counseling to all } \\
\text { parents } \\
\text {-Contact person: Named person from the staff had } \\
\text { more overarching and in-depth responsibility for the } \\
\text { family } \\
\text {-Peer-to-peer groups: Member of staff who } \\
\text { volunteers to be the leader/facilitator for parents to } \\
\text { discuss some topics of choice }\end{array}$ & $\begin{array}{l}\text { - Therapeutic communication with the } \\
\text { mother } \\
\text {-Empathy for mothers }\end{array}$ \\
\hline
\end{tabular}

NICU, neonatal intensive care unit. 
Table 2. General Characteristics of Mothers $(N=10)$

\begin{tabular}{|c|c|c|c|c|c|c|c|}
\hline Participants & $\begin{array}{l}\text { Age } \\
\text { (year) }\end{array}$ & $\begin{array}{c}\text { Gestational age } \\
\text { (week) }\end{array}$ & $\begin{array}{c}\text { Baby's birth } \\
\text { weight (g) }\end{array}$ & $\begin{array}{c}\text { Baby's age } \\
\text { (month) }\end{array}$ & Birth order & $\begin{array}{l}\text { Primary } \\
\text { caregiver }\end{array}$ & Cohabitant \\
\hline A & 22 & $33+0$ & 1,240 & 8 & 1 st & Mother & Husband \\
\hline B & 30 & $31+3$ & 1,400 & 10 & 1 st & Mother & Husband, grandmother \\
\hline C & 32 & $24+6$ & 655 & 5 & 1 st & Mother & Husband \\
\hline $\mathrm{D}$ & 42 & $34+2$ & 2,000 & 2 & 1st & Mother & Husband \\
\hline $\mathrm{E}$ & 31 & $32+4$ & 1,870 & 4 & 1 st & Mother & Husband \\
\hline $\mathrm{F}$ & 37 & $33+3$ & 2,000 & 1 & 2nd & Mother & Husband \\
\hline G & 39 & $26+6$ & 1,050 & 6 & 2nd & Mother & Husband \\
\hline $\mathrm{H}$ & 43 & $33+0$ & 1,870 & 1 & 1 st & Mother & Husband \\
\hline I & 40 & $28+6$ & 960 & 1 & 2nd & Mother & Husband \\
\hline $\mathrm{J}$ & 38 & $32+0$ & 1,400 & 1 & 1st & Mother & Husband, grandmother \\
\hline
\end{tabular}

understand the participants' ideas and responses by listening to the recorded files and reviewing the transcriptions repeatedly. From the transcribed data, the researchers underlined meaningful statements related to nursing support for mothers of premature infants and identified and classified semantic units that contained the concept of implicit nursing support. All the researchers have experience in qualitative research and participated in qualitative research workshops to learn research methodology. In order to be rigorous in our qualitative inquiry, peer review debriefing was carried out with five professors with experience in qualitative research with specialties in maternity and child nursing. In addition, member checking was conducted by sharing the research results with two research participants [13].

\section{4) Ethical considerations}

This study was approved by the institutional review board (IRB) of the university (No. 2017-11-006-001). In addition, prior to the interview, all participants were informed of the purpose of the study and how to proceed with the interview. All participants were informed that their data would only be used as research material and were asked to provide written consent. All data and participant information were anonymously marked by assigning unique numbers, which were kept separately in a designated space with restricted access. After the end of the meeting, a mobile gift card worth approximately 45 USD was presented.

\section{Analytical Phase}

The attributes of nursing support identified during the theoretical phase and the fieldwork phase were compared and analyzed. The researchers stepped back from the intensity and details of the fieldwork and reexamined the findings in light of the initial focus of interest. Definitions, attributes, and indicators of nursing support for mothers of premature infants were subsequently determined in this study.

\section{RESULTS}

\section{Theoretical Phase}

A literature review was conducted to find the components and attributes of nursing support for mothers of premature infants.

\section{1) Dictionary meaning of nursing support}

Nursing support is a compound word consisting of the words "nursing" and "support". The definition of nursing is "the job or skills of a nurse, or the professional training that nurses receive" [14]. The definition of support is "to help someone and be kind to them when they are having a difficult time" [15]. Based on the dictionary definition, nursing support is a nurse's professional behavior of assisting the participants during a difficult time.

\section{2) Support identified in other academic disciplines}

Social support is classified as formal and informal support depending on the provider, and formal support refers to services received from experts or semi-professionals in a structured community or institution [16]. Each scholar defines social support slightly differently, but they each stress interrelationships, providing assistance, and the facilitation of positive outcomes for the subjects of stress or crisis [17]. Social 
support can be used as a nursing intervention to promote subjects' health. Social support provided by nurses to subjects in a hospital can be classified as informal support [16,17].

\section{3) Nursing support in the nursing discipline}

Nursing support is a mutually beneficial relationship forged when a nurse recognizes the support needs of a subject in a stress or crisis situation [18]. Types of nursing support are divided into physical, social, and emotional support [19]. Physical support refers to when nurses apply their knowledge to provide professional technical care, making the patients feel physically cared for $[18,19]$. Emotional support is the most common way for nurses to express support. It entails practicing empathy, which includes listening to patients with an attitude of interest and understanding while they express themselves [18]. Social support is defined by nurses as the provision of assistance in social functions, interactions, and information such as the specific methods and knowledge needed to solve problems [19].

\section{4) Nursing support for mothers of preterm infants}

Nine attributes of nursing support were discovered after reviewing 16 articles (Tables 1, 3). "Caring for premature infants" refers to nurses caring to improve infants' comfort. "Providing information related to the disease" includes the sharing of information related to a baby's treatment process, test results, and body appearance with mothers. "Providing information related to the support system" refers to the introduction of peer-groups and social psychology experts, as well as providing an inpatient environment for mothers. "Providing information related to child rearing" refers to nurses sharing information with mothers regarding a baby's living habits in the NICU and post-discharge management. "Attitudes of information providing nurses" means sharing accurate and transparent information with mothers in a friendly manner. "Empathy for mothers" means being concerned with the mother's worries and giving them the opportunity to share their memories of the baby. "Therapeutic communication with the mother" means listening to the mother's emotional expressions as well as welcoming and being next to mothers. "Improvement of the maternal role" refers to encouraging mothers to participate in the baby's care, which may include kangaroo care and discharge education. "Reinforcement of the maternal role" includes encouraging, acknowledging, and providing feedback to mothers. The nine attributes were categorized into four themes: baby care support, information delivery support, mental care support, and maternal role support.

The working definition of nursing support perceived by mothers of preterm infants is the mutual relationship between nurses and mothers, which includes baby care support for the baby's comfort, information delivery support for providing information related to a disease, a support system, child rearing with a warm attitude, mental care support, therapeutic communication with the mother and support to improve and reinforce the maternal role in mothers.

\section{Fieldwork Phase}

Ten mothers of premature infants were interviewed to identify the four themes and 10 attributes of nursing support from their perspective.

\section{1) Baby care support}

(1) Professional care

Professional care refers to the application of professional knowledge to care for the baby and facilitate an immediate response to the baby's nursing needs.

She was really smart. She knows everything about my baby. I felt relieved when someone with a lot of knowledge looked after my child. (Mother B)

Whenever I visited my baby, he was crying, whining, or the monitor alarmed. I watched the nurse respond immediately. I felt relieved that she would be watching my baby even if I was not there. (Mother G)

(2) Emotional care for the baby

Emotional care means that the baby is given necessary loving attention.

As a mother, I feel compelled to have expectations for a nurse's role. I want a nurse to provide the attention and love that I cannot give my baby. (Mother D)

\section{2) Information delivery support}

(1) Providing information related to the disease

Mothers required an explanation of the treatment process for a baby's disease and information related to coping with symptoms after discharge.

The additional things that the nurses explained to me helped a lot. What did this test do, and maybe the baby would react to it this way... Talking about the process helped me understand the baby's treatment. (Mother A)

(2) Providing information related to the support system

Mothers required guidance regarding the inpatient environment of the baby and the institutions and policies that provide financial support. 
Table 3. Themes, Attributes, and Indicators of Nursing Support as Perceived by Mothers of Preterm Infants in the Analytical Phase

\begin{tabular}{|c|c|c|c|c|}
\hline \multirow{2}{*}{ Themes } & \multicolumn{2}{|c|}{ Attributes } & \multirow{2}{*}{ Final attributes } & \multirow{2}{*}{ Indicators } \\
\hline & Theoretical phase & Fieldwork phase & & \\
\hline \multirow[t]{2}{*}{$\begin{array}{l}\text { Baby care } \\
\text { support }\end{array}$} & $\begin{array}{l}\text { Caring for } \\
\text { premature } \\
\text { infants }\end{array}$ & Professional care & Professional care & $\begin{array}{l}\text { - Caring based on expert knowledge } \\
\text { - Caring to maintain the baby's basic comfort } \\
\text { - Caring reflecting on the characteristics of the baby } \\
\text { - Caring for immediate response to nursing needs }\end{array}$ \\
\hline & & $\begin{array}{l}\text { Emotional care } \\
\text { for the baby }\end{array}$ & $\begin{array}{l}\text { Emotional care for } \\
\text { the baby }\end{array}$ & $\begin{array}{l}\text { - Emotional stimulation for the baby } \\
\text { - Therapeutic communication between baby and } \\
\text { nurse }\end{array}$ \\
\hline \multirow[t]{4}{*}{$\begin{array}{l}\text { Information } \\
\text { delivery } \\
\text { support }\end{array}$} & $\begin{array}{l}\text { Providing } \\
\text { information } \\
\text { related to the } \\
\text { disease }\end{array}$ & $\begin{array}{l}\text { Providing } \\
\text { information } \\
\text { related to the } \\
\text { disease }\end{array}$ & $\begin{array}{l}\text { Information related } \\
\text { to the disease }\end{array}$ & $\begin{array}{l}\text { - Explanation of the coping strategies according to } \\
\text { the baby's symptoms } \\
\text { - Explanation of the physical characteristics that } \\
\text { are distinct from full-term babies } \\
\text { - Explanation to understand the baby's treatment } \\
\text { process }\end{array}$ \\
\hline & $\begin{array}{l}\text { Providing } \\
\text { information } \\
\text { related to the } \\
\text { support system }\end{array}$ & $\begin{array}{l}\text { Providing } \\
\text { information } \\
\text { related to the } \\
\text { support system }\end{array}$ & $\begin{array}{l}\text { Information related } \\
\text { to inpatient } \\
\text { environment }\end{array}$ & $\begin{array}{l}\text { - Introduction of the NICU environment } \\
\text { - Introduction of resources available for financial } \\
\text { assistance } \\
\text { - Introduction of peer groups consisting of mothers } \\
\text { of premature infants } \\
\text { - Introduction of psychological experts who can } \\
\text { assist in coping with psychological difficulties }\end{array}$ \\
\hline & $\begin{array}{l}\text { Providing } \\
\text { information } \\
\text { related to child } \\
\text { rearing }\end{array}$ & $\begin{array}{l}\text { Providing general } \\
\text { information on } \\
\text { baby }\end{array}$ & $\begin{array}{l}\text { Information related } \\
\text { to the baby's daily } \\
\text { hospital life }\end{array}$ & $\begin{array}{l}\text { - Explanation to understand the baby's behavior } \\
\text { and characteristics } \\
\text { - Explanation of the baby's daily life in NICU }\end{array}$ \\
\hline & $\begin{array}{l}\text { Attitudes of } \\
\text { information } \\
\text { providing } \\
\text { nurses }\end{array}$ & $\begin{array}{l}\text { Active attitude of } \\
\text { nurses }\end{array}$ & $\begin{array}{l}\text { Mother-centered } \\
\text { information }\end{array}$ & $\begin{array}{l}\text { - Providing an understandable level of information } \\
\text { - Friendly atmosphere to be able to ask questions } \\
\text { - Providing enough information from mothers' } \\
\text { perspectives } \\
\text { - Efforts to answer the mother's questions }\end{array}$ \\
\hline \multirow[t]{2}{*}{$\begin{array}{l}\text { Mental care } \\
\text { support }\end{array}$} & $\begin{array}{l}\text { Empathy for } \\
\text { mothers }\end{array}$ & $\begin{array}{l}\text { Empathy for } \\
\text { mothers }\end{array}$ & Empathy for mothers & $\begin{array}{l}\cdot \text { Empathy for mother's emotional expressions } \\
\cdot \text { Empathy for separation of the baby }\end{array}$ \\
\hline & $\begin{array}{l}\text { Therapeutic } \\
\text { communication } \\
\text { with the mother }\end{array}$ & $\begin{array}{l}\text { Therapeutic } \\
\text { communication } \\
\text { with the mother }\end{array}$ & $\begin{array}{l}\text { Therapeutic } \\
\text { communication } \\
\text { with the mother }\end{array}$ & $\begin{array}{l}\text { - A welcoming attitude toward mothers } \\
\text { - Listening attentively and responding well } \\
\text { - Words that give mothers the strength to bear with } \\
\text { the situation } \\
\text { - Keeping the mother company }\end{array}$ \\
\hline \multirow[t]{2}{*}{$\begin{array}{l}\text { Maternal } \\
\text { role } \\
\text { support }\end{array}$} & $\begin{array}{l}\text { Improvement of } \\
\text { the maternal role }\end{array}$ & $\begin{array}{l}\text { Providing a } \\
\text { chance for the } \\
\text { mother to take } \\
\text { care of the baby }\end{array}$ & $\begin{array}{l}\text { Providing a chance } \\
\text { for the mother to } \\
\text { take care of the } \\
\text { baby }\end{array}$ & $\begin{array}{l}\cdot \text { Helping mothers make decisions } \\
\text { - Providing maternal experience through tangible } \\
\text { contact } \\
\text { - Providing maternal role experience by } \\
\text { participating in caring }\end{array}$ \\
\hline & $\begin{array}{l}\text { Reinforcement of } \\
\text { the maternal role }\end{array}$ & $\begin{array}{l}\text { Reinforcement of } \\
\text { the maternal } \\
\text { role }\end{array}$ & $\begin{array}{l}\text { Reinforcement of the } \\
\text { maternal role }\end{array}$ & $\begin{array}{l}\cdot \text { Feedback on maternal role } \\
\text { - Compliments and recognition of the maternal } \\
\text { role } \\
\text { - Encouragement to increase mother's self-esteem }\end{array}$ \\
\hline
\end{tabular}

NICU, neonatal intensive care unit. 
The nurse said, 'this is an oxygen giving tube'. 'This is a fluid tube to ensure that the baby gets enough nourishment'. 'This is an incubator with temperature and humidity control'. After receiving that explanation, I deeply understood my baby's situation. (Mother C)

The nurse told me about the financial support program for premature babies. Honestly, I was worried about money, but it helped me a lot. (Mother G)

(3) Providing general information on the baby

This refers to information on the baby's behavior, characteristics, and daily life in the NICU.

That nurse was like a neighbor who talks about everything. I feel like this kind of general chat was more helpful than medical information. (Mother J)

(4) Active attitude of nurses

Nurses must actively answer questions and create a comfortable atmosphere for asking questions.

She always said, if you have any questions, feel free to ask. Every time I visited the NICU, I wished she was there that day. (Mother E)

\section{3) Mental care support}

(1) Empathy for mothers

Mothers said that nurses provided support when they expressed empathy for mothers' feelings and the situation of separation from the baby.

I felt like I was being consoled when the nurse gave me some tissues and sat beside me. (Mother D)

They wrote my baby's rearing diary for me from admission to discharge. (Mother E)

(2) Therapeutic communication with the mother

The participants experienced therapeutic communication when the nurses were welcoming, listened carefully, gave appropriate responses, and said hopeful things such as assurance that the baby would get through the situation.

The nurse always welcomed me with a smile... I got positive energy from the nurse. (Mother F)

Although, it was not always okay, the nurse kept saying positive words to me like 'your baby is holding up very well'. (Mother $\mathrm{H}$ )

\section{4) Maternal role support}

(1) Providing a chance for the mother to take care of the baby
Nurses supported mothers by providing them with opportunities to experience motherhood with direct care for the baby through tangible contact with the baby, such as kangaroo care and direct nursing.

As I was performing kangaroo care, I felt like I was acting as a mother, and I felt proud that I was helping my baby and doing something for her. (Mother J)

The first time I held my baby was during breast-feeding education. (Mother E)

She demonstrated feeding, bathing, and all of the baby rearing activities. It is good for me when I get the chance to practice it. (Mother B)

(2) Reinforcement of the maternal role

Nurses can provide feedback and praise as mothers perform their maternal duties.

It gives me a lot of strength and confidence when she encourages me as a mother. (Mother A)

In a way, like my mother... she taught me, told me how to care of the baby $\cdots$ you can fix these things $\cdots$ I think that's really necessary support for a mother of a premature infant. (Mother D)

\section{Analytical Phase}

A new attribute "emotional care for the baby" was found in the fieldwork phase. As a result of integrating the theoretical and fieldwork phases, nursing support as perceived by mothers of premature infants consisted of four themes, 10 attributes, and 31 indicators (Table 3).

In this study, baby care support was defined as a nurse's professional and emotional care for the baby. Emotional care for the baby was not identified in the theoretical phase, but was included after it was discovered to be an important attribute of nursing support during the fieldwork phase. Information delivery support was important in how well information was shared with mothers. The introduction of peer group support and social psychologists was not included in the fieldwork phase, but was included in the theoretical phase as it was identified as an important form of support. There was not much difference in mental care support between the theoretical and fieldwork phases. Empathy and therapeutic communication for mothers were emphasized in the fieldwork phase. The maternal role was emphasized when nurses assisted the participants in playing the role of a mother. Assisting a mother in the decision-making process was also added, as it was an important indicator in the theoretical phase.

The definition of nursing support as perceived by mothers 
of premature infants was based on attributes identified through the final analytical phase and the ability of the nurses in the NICU to help the participants develop functional skills and strengths to better adapt to the situation of being a mother with a premature baby. These attributes baby care support, which refers to the quality of care that is actually provided to the baby; information delivery support, which refers to the sharing of information to help the mother understand and adapt to the baby's hospitalization; mental care support, which refers to support provided to mothers to help them psychologically adjust to the baby's hospitalization situation; and maternal role support, which refers to support provided to the strengthen the maternal role and enhances self-esteem in mothers.

\section{DISCUSSION}

Nurses support mothers of premature infants, who are experiencing psychological and emotional difficulties, and assist them in coping with the unexpected situation of their baby's hospitalization [5]. In this study, the effort to identify the concepts and attributes of nursing support as perceived by mothers of premature infants was a meaningful attempt to gain clarity in terms of knowledge of the relevant areas. As nursing support depends on the clients and the situation $[8,9]$, the concept of nursing support should be more defined, including as it pertains to a nurse's professionalism and a subject's specific situation.

\section{Baby Care Support}

In professional care, nurses' expertise and knowledge was emphasized at all phases. Caring based on nurses' professional knowledge can enhance parents' satisfaction and assure them that their baby is receiving high-quality care [20]. Nurses with sufficient knowledge of developmental care for preterm infants can provide high-quality developmental care for babies [21]. The need for professional knowledge among nurses in the NICU has been recognized, and some nursing schools have graduate programs for NICU nurses [22]. In addition, hospitals are trying to recruit well-educated nurses by emphasizing certificates and programs that they need to acquire and undertake as NICU nurses [23]. To provide quality care for babies, it is necessary to create an atmosphere that encourages continuing education to provide the best evidencebased care for premature infants.

Professional care was often perceived by the mother through her observations during visiting hours. The mothers said that they identified professional care when they saw a nurse actively responding to a crying baby or monitoring alarms. Kim
[24] also showed that mothers carefully examine nurses' proficiency during the process of performing invasive procedures and treatments to evaluate professionalism. Although professional care is limited to being able to assess and evaluate the behavior of nurses during visiting hours, knowing the quality of professional care helps improve the mother's satisfaction and trust that efforts will be made to meet the mother's needs in terms of baby care.

In the fieldwork phase of this study, emotional care for babies was important. According to the mothers, nurses in the NICU need to provide emotional stability and affection to babies, rather than simply providing professional nursing care. Providing emotional stimulation was underestimated in the theoretical phase. Previous studies have shown that emotional stimulation plays an important role in neurodevelopment and brain maturity [25]. The cuddle program is one of the most famous programs for the emotional support of premature infants. This program helps infants to grow by exposing them to nurses or educated volunteers who talk, hug, or sing to the baby [26]. Although it is still difficult to apply such a program in South Korea because of the lack of workforce and of awareness regarding the importance of such a program, efforts should be made to provide tangible and emotional stimulation in the care of premature infants.

\section{Information Delivery Support}

According to the literature review, mothers perceived information delivery support as an explanation of the baby's disease, such as the baby's condition or improvement, and lab test results [A8,A9,A11]. Later, in the fieldwork phase, it was found that the mothers perceived explanations of the disease process as more important. Previous studies have also reported that explaining the disease process in an easy-to-understand manner is helpful in reducing anxiety and uncertainty in mothers of premature infants [A5,A9,A11,A13]. Rather than simply listing information, it is necessary to make efforts to convey information in an easy-to-understand way and within context.

The unfamiliar hospital environment is overwhelming for mothers of preterm infants [A4,A8]. In the fieldwork phase, the mothers said that unfamiliar medical devices were especially uncomfortable. In Korea, education for premature mothers is focused on discharge education rather than inpatient education [27]. In the future, a detailed description of the hospitalization environment in the NICU should also be provided to mothers to reflect this situation.

In addition, introducing social psychology experts or peer groups was stressed in the theoretical phase [A4,A8,A16]. In the fieldwork phase, only policies or programs for financial 
support were mentioned. In other countries, specialized counselors work in the NICU to provide counseling to parents, and nurses introduce mothers to veteran parents as a peer group [A4,A5,A8,A16]. In Korea, parents themselves have to find and meet peer groups independently, often on the internet. Considering these points, efforts should be made to provide a more friendly environment to mothers of preterm infants.

In the fieldwork phase, the participants wanted to constantly monitor the baby's movements in the hospital rather than receiving information on the baby's disease. Mothers of premature infants often asked what the baby was doing on any given day. In the medical system in Korea, nurses provide limited medical information for reasons of accountability [28]. Usually, parents can obtain information related to their baby's disease from medical doctors rather than nurses. Thus, the fieldwork phase focused on general information about the baby in the hospital.

In addition, mother-centered information was identified as an important part of nursing support. This refers to the communication of information by nurses from the mother's point of view using layman's terms. Nurses act as intermediaries, connecting patients to doctors, explaining difficult medical terms with everyday words, and sometimes providing translation services for foreign patients [A9]. One of the key philosophies of FCC is information sharing, which refers not just to one-sided information. It is important to share accurate information on each level between patients, families, and medical staff. After that, patients' family members can understand how to effectively engage in treatment and decision-making.

In addition, it was confirmed during the fieldwork phase that a nurse's active attitude is important. The mothers expected nurses to do their best to provide information. One mother said that it is important for nurses to try to inform them through other means in the event that they are not able to answer a question. This attitude among nurses is based on FCC, which puts the family first. In this study, it was found that the quality of information, such as the conveying of an understandable level of information to mothers depending on what they needed, was much more important than the quantity of information delivered.

\section{Mental Care Support}

One of the most widely applied forms of nursing support is empathy [A10] for mothers who are separated from their babies. Bry et al. [29] found that NICU nurses engaged in self-centered, purpose-oriented conversations; unfortunately, only $13 \%$ of NICU nurses expressed empathy toward mothers. However, by responding to a mother's feelings through proper expressions of empathy, nurses can help mothers cope with the situation of the baby's hospitalization. This also has an influence on the mother's satisfaction.

Interacting with a mother who is experiencing and dealing with negative emotions, however, can be a burden to the nurse [30]. Knowing nurses' difficulties, hospitals should educate nurses on proper skills to be able to communicate positively with parents in stressful situations and to recognize and respond to parents' feelings.

In addition, the hospital's workforce and physical environment can be improved to enhance nurses' empathy and therapeutic communication skills [A16]. Nurses spend a lot of time performing professional nursing work, with staff shortages causing an increase in stress levels and exhaustion, so they cannot always afford to provide mental care support. In addition, there can be insufficient space to maintain privacy and provide therapeutic communication [29]. Nurses and mothers are partners who must cope with the hardships of a baby's hospitalization for a long time and need to build intimate relationships of trust through mental care support. There should be ongoing discussions about how to help nurses provide high-quality mental care support, such as helping nurses manage stress and burnout and educating them on empathy and therapeutic communication skills.

\section{Maternal Role Support}

Maternal role support was initiated by allowing mothers to have direct contact with the baby, such as kangaroo care or hugging the baby, which is one of the most direct ways to experience motherhood [A3,A11]. Through this contact, the mother can experience a reduction in postpartum depression and improve her maternal confidence, which in turn positively affects the baby's physical, cognitive, mental, and social development [A1,A3,A7].

Furthermore, maternal role support does not end with direct nursing and contact with babies, but also extends to receiving encouragement from nurses. Nurses' compliments, encouragement, and feedback following a mother's performance of maternal roles helps to reinforce those roles for mothers of premature infants. Even mothers who had previously experienced motherhood often complained about not knowing how to care for a premature baby after they are discharged [A10]. In these cases, nurses' compliments and feedback on the mother's role helps the mother to be able to raise the baby at home. Recently, the NICU has devoted a lot of time to mothers' education, including providing booklets related to parenting, discharging education through online communities, home care programs, and telephone counseling [A6,A8]. These programs are well-organized and allow mothers to directly participate in the care of the baby with proper feedback 
from nurses. By strengthening the role of the mother in various ways, a mother's confidence can ultimately improve, influencing the child's health.

\section{CONCLUSION}

In this study, 10 attributes and four themes of nursing support reflecting the mother's point of view in a Korean NICU were identified. Using these results, evidence-based and professional nursing support can be provided to mothers of preterm infants in the NICU. In addition, the development of a nursing support scale is useful for monitoring individual nursing support and enhancing mothers' satisfaction with care and their quality of life.

\section{ORCID}

Mihae Im

https:// orcid.org/0000-0002-3795-5201

Jina Oh https://orcid.org/0000-0002-5883-7538

\section{Authors' contribution}

Conceptualization, Data collection: Mihae Im; Formal analysis: all authors; Writing-original draft: Mihae Im; Writing-review and editing: all authors; Final approval of published version: all authors.

\section{Conflict of interest}

No existing or potential conflict of interest relevant to this article was reported.

\section{Funding}

None.

\section{Data availability}

Please contact the corresponding author for data availability.

\section{Acknowledgements}

A big thank you to all the mothers that participated in the study and were interested in it.

\section{REFERENCES}

1. Myrhaug HT, Brurberg KG, Hov L, Markestad T. Survival and impairment of extremely premature infants: A meta-analysis. Pediartics. 2019;143(2):e20180933. https://doi.org/10.1542/peds.2018-0933

2. Ionio C, Colombo C, Brazzoduro V, Mascheroni E, Confalonieri E, Castoldi F, et al. Mothers and fathers in NICU: The impact of preterm birth on parental distress. Europe's Journal of Psychology. 2016;12(4):604-621. https://doi.org/10.5964/ejop.v12i4.1093

3. Franck LS, Axelin A. Differences in parents', nurses' and physicians' views of NICU parent support. Acta Paediatrica. 2013;102 (6):590-596. https://doi.org/10.1111/apa.12227

4. Stefana A, Lavelli M. Parental engagement and early interactions with preterm infants during the stay in the neonatal intensive care unit: Protocol of a mixed-method and longitudinal study. BMJ Open. 2017;7(2):e013824.

https://doi.org/10.1136/bmjopen-2016-013824

5. Akkoyun S, Tas Arslan F. Investigation of stress and nursing support in mothers of preterm infants in neonatal intensive care units. Scandinavian Journal of Caring Sciences. 2019;33(2):351-358. https://doi.org/10.1111/scs.12630

6. Heidari H, Hasanpour M, Fooladi M. Stress management among parents of neonates hospitalized in NICU: A qualitative study. Journal of Caring Sciences. 2017;6(1):29-38. https://doi.org/10.15171/jcs.2017.004

7. Heydarpour S, Keshavarz Z, Barkhtiari M. Factors affecting adaptation to the role of motherhood in mothers of preterm infants admitted to the neonatal intensive care unit: A qualitative study. Journal of Advanced Nursing. 2017;73(1):138-148. https://doi.org/10.1111/jan.13099

8. Stoltz P, Andersson EP, Willman A. Support in nursing-An evolutionary concept analysis. International Journal of Nursing Studies. 2007;44(8):1478-1489. https://doi.org/10.1016/j.ijnurstu.2006.07.014

9. Gardner KG. Supportive nursing: A critical review of the literature. Journal of Psychiatric Nursing and Mental Health Services. 1979;17(10):10-16.

10. Schwartz-Barcott D, Kim HS. An expansion and elaboration of the hybrid model of concept development. In: Rodgers BL, Knafl KA, editors. Concept development in nursing: Foundations, techniques, and applications. 2nd ed. Philadelphia: Saunders; 2000. p. 129-159.

11. Von Elm E, Altman DG, Egger M, Pocock SJ, Gøtzsche PC, Vandenbroucke JP, et al. The strengthening the reporting of observational studies in epidemiology (STROBE) statement: Guidelines for reporting observational studies. Journal of Clinical Epidemiology. 2008;61(4):344-349. https://doi.org/10.1016/j.jclinepi.2007.11.008

12. Clarke V, Braun V. Thematic analysis. Journal of Positive Psychology. 2017;12(3):297-298. https://doi.org/10.1080/17439760.2016.1262613

13. Morse JM. Critical analysis of strategies for determining rigor in qualitative inquiry. Qualitative Health Research. 2015;25(9):12121222. https://doi.org/10.1177/1049732315588501

14. Macmillan Dictionary. Definition and synonyms of nursing [Inter- 
net]. London: Macmillan Dictionary; 2020 [cited 2020 March 20]. Available from:

https://www.macmillandictionary.com/dictionary/british/nurs ing

15. Macmillan Dictionary. Definition and synonyms of support [Internet]. London: Macmillan Dictionary; 2020 [cited 2020 March 20]. Available from:

https://www.macmillandictionary.com/dictionary/british/sup port

16. House JS. Work stress and social support. Massachusetts: AddisonWesley Publishing Co.; 1981. p. 44-50.

17. Schaffer MA. Social support. In: Peterson SJ, Bredow TS, editors. Middle range theories: Application to nursing research. 2nd ed. Philadelphia, PA: Lippincott Williams and Wilkins; 2009. p. 162-182

18. Kim JA. The effect of supportive nursing care on depression, mood and satisfaction in military patients with low back pain. The Journal of Nurses Academic Society. 1990;20(3):324-340.

https://doi.org/10.4040/jnas.1990.20.3.324

19. Gardner K, Wheeler EC. Nurses' perceptions of the meaning of support in nursing. Issues in Mental Health Nursing. 1981;3(1-2): 13-28. https://doi.org/10.3109/01612848109140858

20. Baghlani R, Hosseini MB, Safaiyan A, Alizadeh M, Bostanabad MA. Neonatal intensive care unit nurses' perceptions and knowledge of newborn individualized developmental care and assessment program: A multicenter study. Iranian Journal of Nursing Midwifery Research. 2019;24(2):113-117. https://doi.org/10.4103/ijnmr.IJNMR_54_18

21. Kim ES, Kim EY, Lee JY, Kim JK, Lee HJ, Lee SH, et al. The effects of supportive nursing management on postpartum depression of mothers with premature infants. Journal of Korean Clinical Nursing Research. 2009;15(3):157-170.

22. Kenner C, Lott JW. Comprehensive neonatal care: An interdisciplinary approach. 4th ed. St. Louis, MO: Saunders; 2007. p. 6627.

23. Nurse.org. Career guide series: Neonatal intensive care [Internet]. Nurse.org; 2020 [cited 2020 March 20]. Available from: https://nurse.org/resources/neonatal-nicu-nurse

24. Kim M. The mother's experience of trusting a nurse with hospitalizing children [master's thesis]. Seoul: Seoul National University; 2017. p. 1-85.

25. Niemi AK. Review of randomized controlled trials of massage in preterm infants. Children. 2017;4(4):21. https://doi.org/10.3390/children4040021

26. Milanaik R, Sidhu S, Spinazzola R. NICU cuddlers: Prevalence and training requirements for therapeutic touch volunteers. Pediatrics. 2019;144(2 Meeting Abstract):688.

27. Im M, Oh J. Integrative review on caring education papers for parents with premature infant. Child Health Nursing Research. 2013; 19(2):120-129. https://doi.org/10.4094/chnr.2013.19.2.120

28. Beom KC. A study on the legal responsibility of nurse. Journal of the Korean Society of Law and Medical. 2014;15(2):285-316.

29. Bry K, Bry M, Hentz E, Karlsson HL, Kyllönen H, Lundkvist M, et al. Communication skills training enhances nurses' ability to respond with empathy to parents' emotions in a neonatal intensive care unit. Acta Paediatrica. 2016;105(4):397-406.

https://doi.org/10.1111/apa.13295

30. Hall SL, Ryan DJ, Beatty J, Grubbs L. Recommendations for peerto-peer support for NICU parents. Journal of Perinatology. 2015;35 (Suppl 1):S9-S13. https://doi.org/10.1038/jp.2015.143 


\section{Appendix 1. Citations of Studies Included in this Study}

A1. Mok E, Leung SF. Nurses as providers of support for mothers of premature infants. Journal of Clinical Nursing. 2006;15(6):726-734. https:// doi.org/10.1111/j.1365-2702.2006.01359.x

A2. Kim ES, Kim EY, Lee JY, Kim JK, Lee HJ, Lee SH, et al. The effects of supportive nursing management on postpartum depression of mothers with premature infants. Journal of Korean Clinical Nursing Research. 2009;15(3):157-170.

A3. Kearvell H, Grant J. Getting connected: How nurses can support mother/infant attachment in the neonatal intensive care unit. The Australian Journal of Advanced Nursing. 2010;27(3):75-82.

A4. Brett J, Staniszewska S, Newburn M, Jones N, Taylor L. A systematic mapping review of effective interventions for communicating with, supporting and providing information to parents of preterm infants. BMJ Open. 2011;1(1):e000023. https://doi.org/10.1136/bmjopen-2010-000023

A5. Bracht M, O'Leary L, Lee SK, O'Brien K. Implementing family-integrated care in the NICU: A parent education and support program. Advances in Neonatal Care. 2013;13(2):115-126. https://doi.org/10.1097/ANC.0b013e318285fb5b

A6. Doron MW, Trenti-Paroli E, Linden DW. Supporting parents in the NICU: A new app from the US, 'MyPreemie': A tool to provide parents of premature babies with support, empowerment, education and participation in their infant's care. Journal of Neonatal Nursing. 2013;19(6):303-307. https://doi.org/10.1016/j.jnn.2013.08.005

A7. Lee TY, Wang MM, Lin KC, Kao CH. The effectiveness of early intervention on paternal stress for fathers of premature infants admitted to a neonatal intensive care unit. Journal of Advanced Nursing. 2013;69(5):1085-1095. https://doi.org/10.1111/j.1365-2648.2012.06097.x

A8. Abdeyazdan Z, Shahkolahi Z, Mehrabi T, Hajiheidari M. A family support intervention to reduce stress among parents of preterm infants in neonatal intensive care unit. Iranian Journal of Nursing and Midwifery Research. 2014;19(4):349-353.
A9. Han SY, Chae SM. Perceived parental stress and nursing support for fathers of high risk infants. Child Health Nursing Research. 2016;22(3):190-198. https://doi.org/10.4094/chnr.2016.22.3.190

A10. Toral-López I, Fernóndez-Alcántara M, González-Carrión P, Cruz-Quintana F, Rivas-Campos A, Pérez-Marfil N. Needs perceived by parents of preterm infants: Integrating care into the early discharge process. Journal of Pediatric Nursing. 2016;31(2):E99-E108. https://doi.org/10.1016/j.pedn.2015.09.007

A11. Heydarpour S, Keshavarz Z, Barkhtiari M. Factors affecting adaptation to the role of motherhood in mothers of preterm infants admitted to the neonatal intensive care unit: A qualitative study. Journal of Advanced Nursing. 2017;73(1):138-148. https://doi.org/10.1111/jan.13099

A12. Huenink E, Porterfield S. Parent support programs and coping mechanisms in NICU parents. Advances in Neonatal Care. 2017; 17(2):E10-E18. https://doi.org/10.1097/ANC.0000000000000359

A13. Shimizu A, Mori A. Maternal perceptions of family-centred support and their associations with the mother-nurse relationship in the neonatal intensive care unit. Journal of Clinical Nursing. 2018; 27(7-8):e1589-e1599. https:// doi.org/10.1111/jocn.14243

A14. Tandberg BS, Frøslie KF, Flacking R, Grundet H, Lehtonen L, Moen A. Parent-infant closeness parents' participation, and nursing support in single-family room and open bay NICUs. Journal of Perinatal and Neonatal Nursing. 2018;32(4):E22-E32. https://doi.org/10.1097/JPN.0000000000000359

A15. Bry A, Wigert H. Psychosocial support for parents of extremely preterm infants in neonatal intensive care: A qualitative interview study. BMC Psychology. 2019;7(1):76. https://doi.org/10.1186/s40359-019-0354-4

A16. Flacking R, Breili C, Eriksson M. Facilities for presence and provision of support to parents and significant others in neonatal units. Acta Paediatrica. 2019;108(12):2186-2191. https://doi.org/10.1111/apa.14948 